\title{
Physico-chemical characterization of chitosan-based edible films incorporating bioactive compounds of different molecular weight
}

\author{
Ana I. Bourbon ${ }^{a}$, Ana C. Pinheiro ${ }^{a}$, Miguel A. Cerqueira ${ }^{a}$, Cristina M.R. Rocha ${ }^{b}$, Maria C. Avides ${ }^{a}$, \\ Mafalda A.C. Quintas ${ }^{\mathrm{a}, \mathrm{c}}$, António A. Vicente ${ }^{\mathrm{a}, *}$ \\ ${ }^{a}$ IBB - Institute for Biotechnology and Bioengineering, Centre of Biological Engineering, Universidade do Minho, Campus de Gualtar, 4710-057 Braga, Portugal \\ ${ }^{\mathrm{b}}$ REQUIMTE - Department of Chemical Engineering, Faculty of Engineering, University of Porto, Rua Dr. Roberto Frias, $4200-465$ Porto, Portugal \\ ${ }^{\mathrm{C}} \mathrm{CBQF} /$ Escola Superior de Biotecnologia, Rua Dr. Antonio Bernardino de Almeida, 4200-072 Porto, Portugal
}

\section{A R T I C L E I N F O}

\section{Article history:}

Received 13 December 2010

Received in revised form 15 March 2011

Accepted 19 March 2011

Available online 25 March 2011

\section{Keywords:}

Edible films

Bioactive compounds

Mechanical properties

Barrier properties

\begin{abstract}
A B S T R A C T
Chitosan packaging films containing different bioactive compounds (a peptide fraction from whey protein concentrate (WPC) hydrolysate, glycomacropeptide (GMP) and lactoferrin) were produced and their mechanical and barrier properties were evaluated. The molecular weight of protein-based compounds was determined using SDS-PAGE. The addition of GMP and lactoferrin to chitosan film caused a significant reduction of tensile strength and the elongation-at-break significantly increased with the incorporation of lactoferrin. The addition of protein-based compounds also affected gas permeability: a significant decrease in water vapor permeability was observed with the incorporation of lactoferrin; oxygen permeability significantly decreased with the addition of GMP and lactoferrin and carbon dioxide permeability significantly decreased with the incorporation of all of the protein-based compounds. Such results were related with film's hydrophilicity and crystallinity.

This manuscript contributes to the establishment of an approach to optimize edible films performance based on physico-chemical properties, aiming at a higher benefit for the consumer.
\end{abstract}

() 2011 Elsevier Ltd. All rights reserved.

\section{Introduction}

Nowadays, packaging plays a decisive role in the improvement of the shelf life of food products and new packaging materials derived from renewable sources are being developed (Lin and Zhao, 2007). The potential of edible films to control gas transfer and to improve food quality, has received increasing attention from researchers and industry, possibly due to their numerous advantages over non-biodegradable plastic packaging films (Srinivasa et al., 2007). An edible coating or film has been defined as a thin, continuous layer of edible material formed or placed on or between foods or food components (Bravin et al., 2006). Besides acting as protective barriers, edible films can be used as carriers of bioactive compounds, thus enhancing the functional properties of the food product by promoting health benefits.

In order to diminish film fragility and increase film flexibility and manageability, plasticizers are added into film formation. They reduce the intermolecular forces and increase mobility of polymer chains, thereby improving flexibility and extensibility of the film. On the other hand, plasticizers generally increase water vapor and solute permeability of the film (Gontard et al., 1993; Sobral et al., 2001).

\footnotetext{
* Corresponding author. Tel.: +351253 604419; fax: +351253678986.

E-mail address: avicente@deb.uminho.pt (A.A. Vicente).
}

Edible films and coatings made from carbohydrates generally exhibits lower moisture barriers due to their hydrophilicity (Hiemenz and Rajagopalan, 1997). To improve moisture barrier characteristics, hydrophobic compounds such as surfactants could be added to hydrophilic materials. Surfactants could also be used to reduce surface tension of the solution, improving the wettability and adhesion of the coating (Ribeiro et al., 2007; Rodríguez et al., 2006). Chitosan is a natural polymer obtained by deacetylation of chitin, which is the major constituent of the exoskeleton of crustaceans. Chitosan has been proved to be nontoxic, biodegradable, biocompatible and has intrinsic antimicrobial activity, inhibiting the growth of a wide variety of bacteria (Helander et al., 2001; Shahidi et al., 1999). In addition, chitosan is an excellent edible film component due to its film-forming capacity and good mechanical properties and can form transparent films, which may find application in a variety of packaging needs (Srinivasa et al., 2002). Chitosan films have a low permeability to gases $\left(\mathrm{CO}_{2}\right.$ and $\left.\mathrm{O}_{2}\right)$ (Hosokawa et al., 1990) however they are highly permeable to water vapor. In order to improve water barrier properties of chitosan films, various compounds are frequently incorporated (Park and Zhao, 2004; Vargas et al., 2009).

Chitosan-based films have also been claimed as effective carriers of many functional ingredients, such as antimicrobial agents and antioxidants to improve quality of food (Durango et al., 2006; Pranoto et al., 2005). A great number works have studied 
the influence and the behavior of bioactive compounds on films (Min et al., 2010; Sebti and Coma, 2002; Seol et al., 2009). However, the incorporation of milk proteins with functional properties in edible films is underexplored, just a few works reported the use of these bioactive compounds in edible films (e.g. lactoferrin incorporated in chitosan films (Brown et al., 2008) and nisaplin in gelatin films (Min et al., 2010). Such proteins are usually only commercially available as impure mixtures, which may difficult identifying the role of the active compound on changes of film functionality for industrial applications. A diverse range of biological activities can be found in many milk proteins, namely: the hydrolysates produced from whey protein concentrate (WPC) show antihypertensive properties (Mullally et al., 1997); glycomacropeptide (GMP), a peptide derived from k-casein, exhibits antibacterial activity, modulates the immune systems responses and regulates the blood circulation (Thomä-Worringer et al., 2006); or lactoferrin, a glycoprotein that displays antimicrobial, anti-inflammatory and anticancer activities (González-Chávez et al., 2009).

The development of active packaging systems, particularly those exhibiting antimicrobial properties, is a long studied theme (see, e.g. Cai et al., 2010; Martins et al., 2010; Pranoto et al., 2005). However, other important features of such systems, like the impact on films functionality or the release of active components from films, is less studied. The aim of the work reported in this paper is to analyze the effect of the incorporation of peptides and proteins of different molecular weights on the mechanical, thermal and barrier properties of chitosan-based films, together with chemical characteristics.

\section{Materials and methods}

\subsection{Bioactive compounds}

In this work, different bioactive compounds were incorporated into chitosan films: a peptide fraction hydrolyzed from whey protein concentrate (WPC), glycomacropeptide (GMP) and lactoferrin. The peptide fraction was obtained from hydrolysis of WPC (80\% wt of protein, Arla Foods, Denmark) performed based on the methodology described by Ferreira et al. (2007). The generated hydrolysates were subjected to a dialysis using tubular dialysis membrane having defined molecular weight cut-off value of $1.0 \mathrm{kDa}$ (Cellu-Sep H1, Membrane filtration products, USA). Commercial GMP and lactoferrin were obtained from Davisco Food International, Inc. (Le Sueur) and DMV International (USA), respectively.

To determine peptides molecular weight, sodium dodecyl sulfate-polyacrylamide gel electrophoresis (SDS-PAGE) was performed using $4-20 \%$ polyacrylamide gels containing $0.1 \%$ SDS and Tris-glycine buffer containing $0.1 \%$ SDS, at a constant current of $10 \mathrm{~mA}$ in a Mini-Protean Tetra Cell (Bio-Rad, San Francisco). Protein samples $(2.5 \mathrm{mg} / \mathrm{ml})$ mixed with sample buffer containing $10 \%(\mathrm{w} / \mathrm{v})$ of SDS were boiled for $5 \mathrm{~min}$ prior to electrophoresis. An aliquot $(5 \mu \mathrm{l}$ ) of molecular weight standards (Precision Plus Protein all blue standards, Bio-Rad), ranging from 10 to $250 \mathrm{kDa}$, was also loaded onto the same gel. Proteins were visualized with Coomassie Blue R-250 (Sigma, USA).

\subsection{Preparation of chitosan films incorporating bioactive compounds}

Chitosan edible films were prepared by dissolving $2 \%(\mathrm{w} / \mathrm{v})$ of chitosan (90\% deacetylation, Aqua Premier Co., Thailand) in a $1 \%$ lactic acid (Acros Organics, Belgium) solution and stirred, at room temperature, until chitosan was completely dissolved. Glycerol at $1 \%(\mathrm{w} / \mathrm{v})$ (Panreac, Spain) and Tween 80 at $0.2 \%(\mathrm{w} / \mathrm{v})$ (Acros
Organics, Belgium) were added as a plasticizer and as a surfactant, respectively. The addition of glycerol and Tween 80 was based in reported chitosan-based films formulations (Casariego et al., 2008; Cerqueira et al., 2009a). The pH of the film forming solution was 4.5 .

Bioactive compounds were incorporated into chitosan films forming solutions at a concentration of $1 \%$ (dry basis). In order to obtain films with a similar thickness, a constant amount $(28 \mathrm{ml})$ of the chitosan solutions was casted in $8.5 \mathrm{~cm}$ diameter Petri dish and dried in an oven at $35{ }^{\circ} \mathrm{C}$, overnight. The films were stored at $20{ }^{\circ} \mathrm{C}$ (controlled by laboratory air conditioning system) and $53 \%$ $\mathrm{RH}$ (obtained by equilibration in a desiccator with a saturated salt solution of $\mathrm{Mg}\left(\mathrm{NO}_{3}\right)_{2}$, under vacuum), until further use.

\subsection{Characterization of chitosan films incorporating bioactive compounds}

\subsubsection{Film thickness}

The thickness of the produced protein-containing films was measured using a digital micrometer (Mitutoyo, Japan). For each produced sample, six determinations were made at random positions.

\subsubsection{Confocal laser scanning microscopy}

A confocal laser scanning microscope (Olympus Fluoview, FV 1000 , Germany) was used to visualize the proteins incorporated into chitosan films in green fluorescence mode $(488 \mathrm{~nm})$. Proteins were labeled with Fluorescein isothiocyanate (FITC) (Fluka, Germany).

\subsubsection{Moisture content and water solubility}

To determine the moisture content (MC) of films, approximately $50 \mathrm{mg}$ of film were dried at $105^{\circ} \mathrm{C}$ during $24 \mathrm{~h}$ (until the equilibrium weight was attained). The weight loss of the sample was determined, and MC was calculated as the percentage of water removed from the system. The film solubility in water was determined according to the method reported in literature (Cuq et al., 1996).

Three replicates were obtained for each sample.

\subsubsection{Mechanical and thermal properties}

Mechanical properties, tensile strength (TS) and elongation-atbreak $(E)$, were measured with an Instron Universal Testing Machine (Model 4500, Instron Corporation, USA) following the guidelines of ASTM D882-91 (ASTM D882-91, 1991) standard method. The initial grip separation was set at $30 \mathrm{~mm}$ and the crosshead speed was set at $5 \mathrm{~mm} \mathrm{~min}{ }^{-1}$. Tests were replicated nine times for each sample.

Films' thermal properties were obtained through using Differential Scanning Calorimetry (DSC). Measurements were performed with a Shimadzu DSC-50 (Shimadzu Corporation, Kyoto, Japan). Scans ranged from 20 to $250{ }^{\circ} \mathrm{C}$ with $10{ }^{\circ} \mathrm{C} \mathrm{min}-1$ temperature increase. Melting temperature $\left(T_{m}\right)$ and specific enthalpy $\left(\Delta h_{m}\right)$ were determined. Two replicates were obtained for each sample.

\subsubsection{Water vapor permeability measurement}

The measurement of water vapor permeability (WVP) was determined gravimetrically based on the ASTM E96-92 (ASTM E96-92, 1990) method and following Cerqueira et al. (2009b).

The WVP was estimated using regression analysis from Eq. (1) adapted from literature (Sobral et al., 2001):

$\frac{w x}{A \Delta p}=\mathrm{WAP} \times t$

where $x$ is the average thickness of edible films, $A$ is the permeation area $\left(0.005524 \mathrm{~m}^{2}\right) . \Delta P$ is the difference of partial vapor pressure of 
the atmosphere $\left(2337 \mathrm{~Pa}\right.$ at $\left.20^{\circ} \mathrm{C}\right)$ and $w$ as the weight loss. Two replicates were obtained for each sample.

\subsubsection{Oxygen and carbon dioxide permeability}

Oxygen permeability $\left(\mathrm{O}_{2} \mathrm{P}\right)$ and carbon dioxide permeability $\left(\mathrm{CO}_{2} \mathrm{P}\right)$ were determined based on the ASTM D3985-02 (ASTM D3985-02, 2002) method described by Cerqueira et al. (2009b).

$\mathrm{O}_{2} \mathrm{P}$ was measured at $20 \pm 2{ }^{\circ} \mathrm{C}$ and $50 \pm 1 \% \mathrm{RH}$ using an $\mathrm{O}_{2}$ sensor (Mettler-Toledo, Switzerland). In the case of, $\mathrm{CO}_{2} \mathrm{P}$ was determined by gas chromatography (Chrompack 9001, Middelburg, Netherlands) with a column Porapak Q 80/100 mesh $2 \mathrm{~m} \times 1$ / $8^{\prime \prime} \times 2 \mathrm{~mm}$ SS to separate the $\mathrm{CO}_{2}$ and with a column molecular sieve $5 \mathrm{~A} 80 / 100$ mesh $1 \mathrm{~m} \times 1 / 8^{\prime \prime} \times 2 \mathrm{~mm}$ to separate the $\mathrm{O}_{2}$ followed by a thermal conductivity detector (TCD) at $110^{\circ} \mathrm{C}$. Helium at23 $\mathrm{mL} \mathrm{min}^{-1}$ was used as carrier gas. A mixture containing $10 \%$ $\mathrm{CO}_{2}, 20 \% \mathrm{O}_{2}$, and $70 \% \mathrm{~N}_{2}$ was used as the standard for calibration. Two replicates were obtained for each sample, in each case $\left(\mathrm{O}_{2} \mathrm{P}\right.$ and $\left.\mathrm{CO}_{2} \mathrm{P}\right)$. For each replicate three measurements were taken.

\subsubsection{FTIR analysis}

Infrared (IR) spectra were recorded using ATR regime using a Perkin-Elmer 16 PC spectrometer (Perkin-Elmer, Boston, USA) in the wave number region $600-4000 \mathrm{~cm}^{-1}$ using 16 scans at a $1 \mathrm{~cm}^{-1}$ of resolution. Before film analysis, an open bean background spectrum of clean crystal was recorded. Data analysis of each film was performed with Peak Fit 4.12 (SYSTAT Software Inc., Richmond, CA, USA) program. Spectra of films have been deconvoluted with the second derivative method with a smoothing filter set at $20 \%$.

\subsubsection{Statistical analysis}

The statistical analyses of the data were performed using Analysis of Variance (ANOVA), Tukey mean comparison test $(p<0.05)$ and regression analysis (EXCEL 2007 and SigmaStat, trial version, 2003, USA).

\section{Results and discussion}

\subsection{Characterization of bioactive proteins and peptides weight}

The bioactive proteins and peptides were examined using SDSPAGE and the protein profiles are shown in Fig. 1, which shows the proteins separated by SDS-PAGE (Laemmli, 1970). Lane 1 contains the protein fragment of the digested WPC (fraction subjected to a

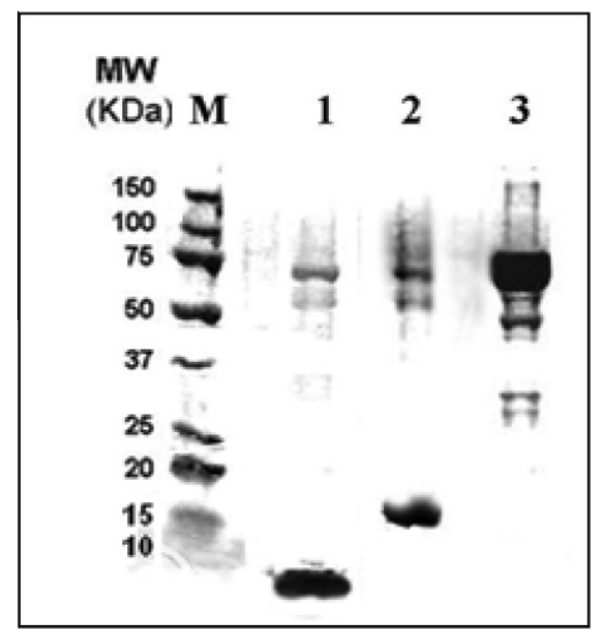

Fig. 1. SDS-PAGE patterns of: (M) molecular mass protein standards, (1) WPC hydrolysate (peptide fraction), (2) GMP, (3) lactoferrin. separation through a membrane dialysis). Most of the peptides fraction exhibits molecular weights smaller than $10 \mathrm{kDa}$. The peptide fraction SDS-PAGE band profiles also show the minor presence of other proteins located between 60 and $75 \mathrm{kDa}$ that are nonhydrolyzed proteins (probably Bovine Serum Albumin (BSA)) that appear not to be efficiently separated through the dialysis process.

The analysis of GMP by SDS-PAGE (lane 2) gave minor and major broad bands. The major irregular band had a mass of 15$20 \mathrm{kDa}$, corresponding to aggregated forms of GMP; whereas a minor band was located between 50 and $75 \mathrm{kDa}$, corresponding to the presence of other proteins reflecting its low purity. Farías et al. (2010) also reported the existence of other proteins, such as $\beta$-lactoglobulin and $\alpha$-lactalbumin, in a partially purified GMP, located immediately following the major GMP band.

Lactoferrin was also identified by SDS-Page as a band of $79 \mathrm{kDa}$ (lane 3). The electrophoresis profile of lactoferrin revealed the presence of other proteins bands such as $\beta$-casein (35 kDa), reflecting the non-purity of lactoferrin sample (Lindmark-Månsson et al., 2005).

These results allowed determining the average molecular weights of the protein-based compounds: 8.91, 20.12 and $80.79 \mathrm{kDa}$ for peptide fraction from the hydrolysate of WPC, GMP and lactoferrin, respectively.

\subsection{Films morphology}

The combination of the principles of confocal laser scanning microscopy allows visualizing the morphological structure of the films, mainly the distribution of the constituents in the filmogenic matrix. Confocal laser scanning microscopy images of chitosan matrix and of the chitosan film with the bioactive compounds are shown in Fig. 2.

Chitosan matrix (Fig. 2A) did not show fluorescence, whereas FITC-labeled proteins emitted fluorescence. This allowed visualizing protein distribution in the matrix (Fig. 2B-D). This CLSM images lead to conclude that GMP and lactoferrin are homogeneously distributed in chitosan films, while the peptide fraction
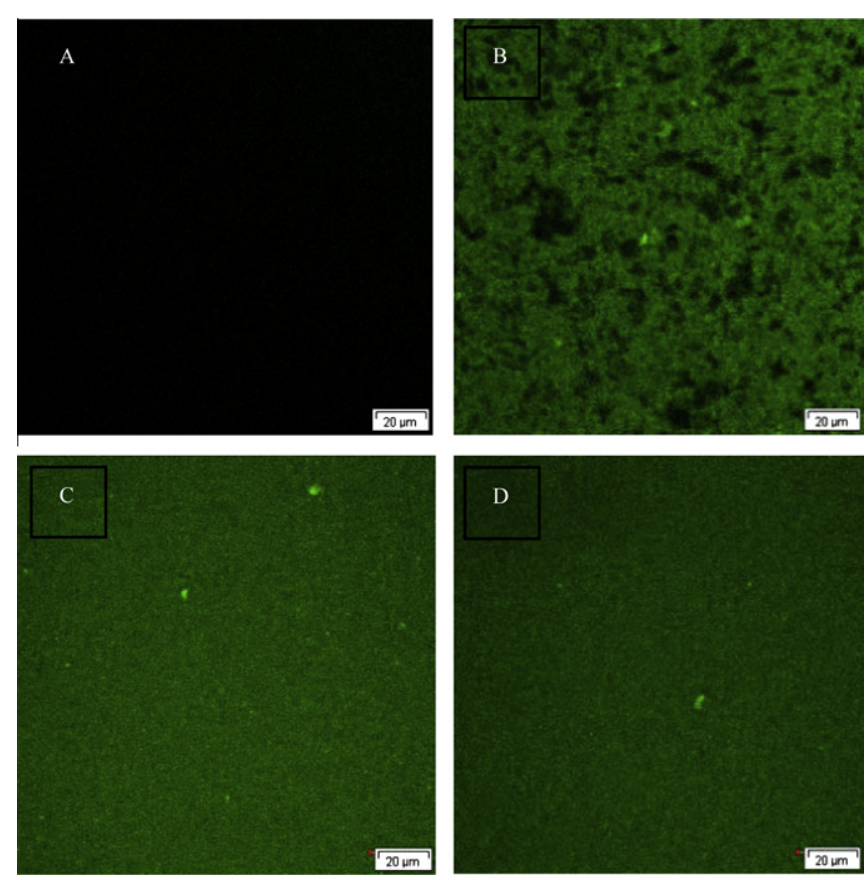

Fig. 2. Micrographs obtained by confocal laser scanning microscopy of the films: (A) chitosan film, (B) chitosan film with WPC hydrolysate + FITC, (C) chitosan film with GMP + FITC and (D) chitosan film with lactoferrin + FITC. 
seems to be non-uniformly distributed in the chitosan matrix. Film thickness was only affected by lactoferrin incorporation, as clearly shown by the results in Table 1 .

In order to evaluate the effect of a possible electrostatic complex formation between the added bioactive compounds and chitosan matrix in films morphology, zeta potential measurements were carried out. The film forming solution (chitosan + glycerol + Tween 80 ) exhibit a zeta potential of $68.3 \mathrm{mV}$ and the peptide fraction, GMP and lactoferrin solutions exhibit zeta potentials of -29.9 , -18.7 and $31.8 \mathrm{mV}$, respectively. These results suggest that an electrostatic interaction can occur between the film forming solution and the peptide fraction or GMP, although no correlation was found between this behavior and films' morphology results.

\subsection{Moisture content and water solubility}

The amount of water present in films provides an indication of the films hydrophilicity, being the more hydrophilic films those that present the highest values of moisture content (Table 1 ). These are in agreement with the results obtained for the same chitosan concentrations reported in literature (Casariego et al., 2009). Incorporating bioactive compounds in chitosan films led to an increase of moisture content. This increase was significant for films incorporated with the hydrolysate of WPC and GMP $(p<0.05)$. These differences are possibly related with the hydrophilicity of the different peptides. Although hydrophilicity of WPC hydrolysate was not characterized, literature reports that GMP is highly hydrophilic (Keogh et al., 2010), while lactoferrin presents both hydrophobic and hydrophilic areas in its conformation (Lu et al., 2005).

The increase of moisture content in the films with bioactive compounds may also be related with the increase of charged molecules, which present a higher ability to adsorb water (Anker et al., 1999).

Water solubility is another parameter that gives indication of the film's water affinity. The water solubility obtained for the chitosan film (Table 1) agrees well with results reported in literature (Souza et al., 2009). Table 1 also shows that solubility increases for films with protein-based compounds, however such increase is not significant $(p>0.05)$.

\subsection{Mechanical and thermal properties}

The intended use of edible coatings or films requires a clear understanding of mechanical properties such as tensile strength (TS) and elongation-at-break (E). These parameters relate mechanical properties of films to their chemical structures and depend strongly on film composition. The interaction of proteins, hydrocolloids and other additives including water, plasticizers and bioactive compounds plays an important role in TS and $E$ of edible films (Sivarooban et al., 2008). TS indicates the maximum tensile stress that the film can sustain and $E$ is the maximum change in length of a test specimen before it breaks.

TS and $E$ values obtained for the different chitosan-based films are shown in Table 1 . Chitosan film without bioactive compounds exhibit a TS value (11.58 MPa) close to the value obtained by Srinivasa et al. (2007) (14.14 MPa) for chitosan films with glycerol as a plasticizer. Addition of GMP and lactoferrin to chitosan films led to a significant reduction $(p<0.05)$ of TS from 11.58 to 7.90 and 2.17 $\mathrm{MPa}$, respectively, while the addition of the peptide fraction from the WPC hydrolysate did not show a significant effect $(p>0.05)$. The incorporation of GMP and lactoferrin into chitosan films probably weakens the interactions between chitosan molecules and may lead to a disruption of three-dimensional structure of the film. Furthermore, it is notorious that the increase of the molecular weight of the protein based compounds incorporated results in a higher reduction of TS. This may be attributed to the higher disarrangement in the matrix interactions caused by the highest molecular weight compounds.

Similar results were obtained when whey proteins were added to chitosan films. The increase of whey protein concentration decreased TS, with values ranging between 15 and $2 \mathrm{MPa}$ (Di Pierro et al., 2006). Also for soy protein films it was observed that the addition of nisin resulted in lower values of TS (from 8.80 to 5.11 MPa, respectively) (Sivarooban et al., 2008).

Concerning the $E$ values, it was observed that the chitosan film without bioactive compounds shows a higher $E(69.84 \%)$ than the one obtained by Ziani et al. (2008) (52.5\%) for chitosan films also with a plasticizer (glycerol) and a surfactant (Tween 20) incorporated. This difference may be related with the higher concentration of glycerol used in this work, once glycerol decreases intermolecular attraction of chitosan chains, increasing the polymer mobility and consequently the films' elongation.

The incorporation of low and medium molecular weight proteins (peptide fraction from the hydrolysate from WPC and GMP, respectively) into chitosan film did not significantly affect $(p>0.05)$ the $E$ values $(69.84-73.64 \%$ and $72.42 \%$, respectively). However, the addition of the higher molecular weight protein (lactoferrin) showed a significant effect $(p<0.05)$ on this parameter. When $E$ is considered, the effects of peptides and their molecular weight on chitosan film properties were more evident. This behavior can be explained by the plasticizer effect of lactoferrin that inserts in the chitosan matrix increasing the free volume of the chitosan chains that leads to higher values of $E$ and to the decrease

Table 1

Hydrophilicity, gas barrier, mechanical and thermal properties of chitosan edible films - effect of incorporation of bioactive compounds.

\begin{tabular}{|c|c|c|c|c|c|c|c|c|c|c|}
\hline \multirow[t]{2}{*}{ Film composition } & \multirow{2}{*}{$\begin{array}{l}\text { Film } \\
\text { thickness } \\
(\mathrm{mm}) \\
(d f>50)\end{array}$} & \multicolumn{2}{|c|}{ Hydrophilicity } & \multicolumn{4}{|c|}{ Mechanical and Thermal properties } & \multicolumn{3}{|c|}{ Gas barrier properties } \\
\hline & & $\begin{array}{l}\text { Moisture } \\
\text { content (\%) } \\
(d f=2)\end{array}$ & $\begin{array}{l}\text { Solubility } \\
(\%) \\
(d f=2)\end{array}$ & $\begin{array}{l}\text { TS } \\
\text { (Mpa) } \\
(d f=8)\end{array}$ & $\begin{array}{l}E(\%) \\
(d f=8)\end{array}$ & $\begin{array}{l}T_{m} \\
\left({ }^{\circ} \mathrm{C}\right)\end{array}$ & $\begin{array}{l}\Delta h_{m} \\
\left(\mathrm{Jg}^{-1}\right)\end{array}$ & $\begin{array}{l}\text { WVP } \\
\left(\mathrm{g} \mathrm{Pa}^{-1} \mathrm{~s}^{-1} \mathrm{~m}^{-1}\right) \\
(d f=10)\end{array}$ & $\begin{array}{l}\mathrm{PO}_{2} \\
\left(\mathrm{~g} \mathrm{~m} \mathrm{~Pa}^{-1} \mathrm{~s}^{-1} \mathrm{~m}^{-2}\right) \\
(d f=7)\end{array}$ & $\begin{array}{l}\mathrm{PCO}_{2} \\
\left(\mathrm{~g} \mathrm{~m} \mathrm{~Pa}^{-1} \mathrm{~s}^{-1} \mathrm{~m}^{-2}\right) \\
(d f=6)\end{array}$ \\
\hline Chitosan & $\begin{array}{l}0.174^{\mathrm{a}} \\
( \pm 0.009)\end{array}$ & $\begin{array}{l}12.72^{\mathrm{a}} \\
( \pm 1.04)^{\mathrm{sd}}\end{array}$ & $\begin{array}{l}42.05^{\mathrm{a}} \\
( \pm 3.46)^{\mathrm{sd}}\end{array}$ & $\begin{array}{l}11.58^{a} \\
( \pm 1.20)\end{array}$ & $\begin{array}{l}69.84^{\mathrm{a}} \\
( \pm 4.08)\end{array}$ & $\begin{array}{l}194.1 \\
( \pm n d)\end{array}$ & $\begin{array}{l}20.74 \\
( \pm n d)\end{array}$ & $\begin{array}{l}1.64 \times 10^{-10 a} \\
\left( \pm 1.85 \times 10^{-11}\right)\end{array}$ & $\begin{array}{l}5.17 \times 10^{-14 a} \\
\left( \pm 4.06 \times 10^{-15}\right)\end{array}$ & $\begin{array}{l}5.86 \times 10^{-13 a} \\
\pm 1.09 \times 10^{-13}\end{array}$ \\
\hline $\begin{array}{l}\text { Chitosan + WPC } \\
\text { fraction }\end{array}$ & $\begin{array}{l}0.186^{\mathrm{a}} \\
( \pm 0.007)\end{array}$ & $\begin{array}{l}15.53^{\mathrm{b}} \\
( \pm 0.39)^{\text {sd }}\end{array}$ & $\begin{array}{l}47.11^{\mathrm{a}} \\
( \pm 3.11)^{\mathrm{sd}}\end{array}$ & $\begin{array}{l}7.36^{\mathrm{ab}} \\
( \pm 2.03)\end{array}$ & $\begin{array}{l}75.77^{\mathrm{a}} \\
( \pm 8.28)\end{array}$ & $\begin{array}{l}190.7 \\
( \pm n d)\end{array}$ & $\begin{array}{l}29.61 \\
( \pm n d)\end{array}$ & $\begin{array}{l}1.40 \times 10^{-10 a b} \\
\left( \pm 1.60 \times 10^{-11}\right)\end{array}$ & $\begin{array}{l}4.38 \times 10^{-14} \mathrm{ab} \\
\left( \pm 4.71 \times 10^{-15}\right)\end{array}$ & $\begin{array}{l}9.86 \times 10^{-14 b} \\
\pm 1.91 \times 10^{-14}\end{array}$ \\
\hline Chitosan + GMP & $\begin{array}{l}0.177^{\mathrm{a}} \\
( \pm 0.006)\end{array}$ & $\begin{array}{l}14.63^{\mathrm{b}} \\
( \pm 0.49)^{\text {sd }}\end{array}$ & $\begin{array}{l}45.39^{\mathrm{a}} \\
( \pm 4.17)^{\text {sd }}\end{array}$ & $\begin{array}{l}7.90^{\mathrm{b}} \\
( \pm 0.97)\end{array}$ & $\begin{array}{l}72.42^{\mathrm{a}} \\
( \pm 7.09)\end{array}$ & $\begin{array}{l}198.6 \\
( \pm n d)\end{array}$ & $\begin{array}{l}26.26 \\
( \pm n d)\end{array}$ & $\begin{array}{l}1.30 \times 10^{-10 a b c} \\
\left( \pm 2.09 \times 10^{-11}\right)\end{array}$ & $\begin{array}{l}2.80 \times 10^{-14 c} \\
\left( \pm 3.86 \times 10^{-15}\right)\end{array}$ & $\begin{array}{l}1.04 \times 10^{-13 \mathrm{~b}} \\
\pm 2.93 \times 10^{-14}\end{array}$ \\
\hline Chitosan + lactoferrin & $\begin{array}{l}0.147^{\mathrm{b}} \\
( \pm 0.002)\end{array}$ & $\begin{array}{l}14.11^{\mathrm{ab}} \\
( \pm 0.59)^{\mathrm{sd}}\end{array}$ & $\begin{array}{l}43.89^{\mathrm{a}} \\
( \pm 3.33)^{\mathrm{sd}}\end{array}$ & $\begin{array}{l}2.17^{\mathrm{c}} \\
( \pm 0.57)\end{array}$ & $\begin{array}{l}100.78^{\mathrm{b}} \\
( \pm 9.90)\end{array}$ & $\begin{array}{l}196.0 \\
( \pm n d)\end{array}$ & $\begin{array}{l}40.26 \\
( \pm n d)\end{array}$ & $\begin{array}{l}1.16 \times 10^{-10 c} \\
\left( \pm 9.13 \times 10^{-12}\right)\end{array}$ & $\begin{array}{l}1.23 \times 10^{-14 d} \\
\left( \pm 3.08 \times 10^{-15}\right)\end{array}$ & $\begin{array}{l}8.54 \times 10^{-14 b} \\
\pm 3.16 \times 10^{-14}\end{array}$ \\
\hline
\end{tabular}

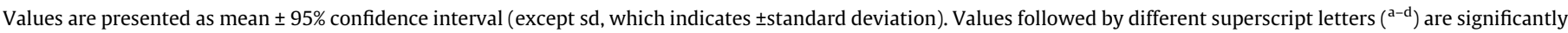
different $(p<0.05)$. df indicates statistical analysis degrees of freedom and nd indicates value not determined. 
of TS. A similar behavior was observed when small peptides were added to gelatin films (Giménez et al., 2009). Similar results were previously observed by other authors (Martins et al., 2010; Pranoto et al., 2005). Also for pullulan films, it has been shown that the addition of rice protein leads to the increase of $E$ values (Shih, 1996). E measures the films ability to stretch, which means that the incorporation of higher molecular weight proteins into chitosan films results in more stretchable films.

Mechanical behavior of polymeric matrices is also dependent on crystallinity. The crystallinity of a polymer is associated with the enthalpy of melting $\left(h_{m}\right)$ obtained e.g. by DSC (Souza et al., 2010; Sperling, 2006). Chitosan film without protein-based compounds shows a $h_{m}$ value very similar to the one obtained by Souza et al. (2010) (Table 1). Also it was observed an increase of specific melting enthalpy $\left(h_{m}\right)$ with addition of protein-based compounds to the films. This indicates an increase on crystallinity of films that can be associated with more breakable (lower TS) and elastic (higher E) films (Ziani et al., 2008).

This increase in film crystallinity may also affect the film morphology previously described. It can be observed (Table 1) that chitosan films containing lactoferrin showed the lower thickness and the higher specific melting enthalpy. Typically, in a crystal lattice structure molecules are oriented while amorphous structures present a more random orientation (Hartel, 2001), which may led to a more "tightly packed", thinner structure in crystals.

Also, the lower crystallinity observed in chitosan films incorporating peptide fraction or GMP is possibly related with the electrostatic interactions which occur between these protein-based compounds and the chitosan matrix, causing a decrease of the binding sites available for crystal formation.

\subsection{Gas barrier properties}

\subsubsection{Water vapor permeability}

Water vapor permeability (WVP) is an important parameter commonly considered in food packaging that comprises sorption, diffusion and adsorption. WVP should be as low as possible since one of the main objectives of the use of an edible film is to retard moisture transfer between the food and the environment (Gontard et al., 1992). The interactions between polymer and water molecules are fundamental to evaluate water permeation through a film, which usually occurs through the hydrophilic part of the film (Sangaj and Malshe, 2004). The relation between hydrophilic and hydrophobic portions is an important factor in WVP determination. WVP values obtained for the films studied in this work are shown in Table 1. Chitosan film without bioactive compounds incorporated exhibit a WVP value similar to the one obtained by other authors (Ziani et al., 2008). The addition of low and medium molecular weight compounds (peptide fraction from WPC hydrolysate and from GMP) to chitosan films did not significantly $(p>0.05)$ influence WVP. However, a significant decrease was observed in WVP with the incorporation of the highest molecular weight protein (lactoferrin). The same behavior was observed by Martins et al. (2010) with the incorporation of a bioactive peptide (nisin) in films of galactomannan. Also for chitosan films it has been shown that the incorporation of soybean trypsin inhibitor extract lead to a decrease of WVP values (Zhang et al., 2009).

Compounds with high hydrogen bonding generate films that are susceptible to water vapor, while compounds with hydrophobic groups make excellent barriers to moisture (Souza et al., 2009). The primary sequence of lactoferrin reveals the presence of many short peptide stretches that are either hydrophobic or hydrophilic (Lu et al., 2005), therefore the decrease of WVP caused by lactoferrin incorporation might be due to the dominance effect of hydrophobic groups present in the lactoferrin molecule. Table 1 also shows that chitosan films with lactoferrin present the lowest value of moisture content when compared with other proteinbased films.

The decrease of gas permeabilities can be also related with film crystallinity. The mass transfer of gas in a semi-crystalline polymer is primarily a function of the amorphous phase, because the crystal line phase is usually assumed to be impermeable. As the percent crystallinity of a polymer increases, the gas permeability decreases (Miller and Krochta, 1997). As previously discussed, Table 1 shows that the energy of melting $\left(h_{m}\right)$ increases for chitosan films with protein-based materials. Therefore the decrease of WVP in the presence of protein-based materials can be associated with the increase of the crystallinity of the chitosan films. Chitosan films containing lactoferrin present the highest value of $h_{m}$ and simultaneously the lowest value of WVP $(p<0.05)$. Similar results were observed for chitosan films where the increase of crystallinity lead to a decrease of WVP (Ziani et al., 2008).

\subsubsection{Oxygen permeability and carbon dioxide permeability}

Oxygen permeability $\left(\mathrm{O}_{2} \mathrm{P}\right)$ of food packaging materials is of great importance for food preservation, since oxygen is the key factor that might originate oxidation, which initiates several deterioration reactions (Sothornvit and Pitak, 2007). By nature, polysaccharide films offer a good oxygen barrier, since their hydrogen-bonded network structure is tightly packed and arranged (Cerqueira et al., 2009b; Martins et al., 2010). Also the measurement of permeability of edible films to carbon dioxide provides important information for the development of edible films, especially for the design of modified atmosphere packaging (McMillin, 2008). Results from $\mathrm{O}_{2} \mathrm{P}$ are presented in Table 1 . The $\mathrm{O}_{2} \mathrm{P}$ value obtained for chitosan film without bioactive compounds is in the range of values reported by other authors (Caner et al., 1998). This property is affected by the type of acids and plasticizers concentrations used in chitosan film formulations (Sathivel et al., 2007). It can be observed that the addition of GMP and lactoferrin (from the proteins used in this study, the ones with intermediate and high molecular weight) significantly decreased $(p<0.05)$ the values of $\mathrm{O}_{2} \mathrm{P}$. However, this effect was not observed with the addition of the lowest molecular weight system (whey protein hydrosylate). The decrease in $\mathrm{O}_{2} \mathrm{P}$ originated by GMP and lactoferrin addition is possibly due to the high molecular weight exhibited by these two protein-based compounds. Also, as previously discussed, gas permeabilities can be related with the crystallinity of the films and it is known that the increase of crystallinity leads to a decrease of $\mathrm{O}_{2} \mathrm{P}$ and $\mathrm{CO}_{2} \mathrm{P}$ (Miller and Krochta, 1997). However, it can be observed that for chitosan films containing WPC hydrolysate the expected $\mathrm{O}_{2} \mathrm{P}$ decrease was not observed. This behavior can be explained by the non-uniform distribution of the peptide fraction in the chitosan matrix (Fig. 2b). Similar results were observed for other chitosan films where the increase of crystallinity lead to a decrease of gas permeability (Souza et al., 2009, 2010).

Table 1 also shows carbon dioxide permeability $\left(\mathrm{CO}_{2} \mathrm{P}\right)$ for chitosan-based films. The $\mathrm{CO}_{2} \mathrm{P}$ value obtained for chitosan film without bioactive compounds incorporated is in agreement with the results reported by other authors (Fajardo et al., 2010). It was observed that the addition of protein-based compounds into chitosan films significantly decrease $(p<0.05) \mathrm{CO}_{2} \mathrm{P}$. However, no statistical difference $(p>0.05)$ was observed between samples with peptides/proteins of different molecular weight. The low diffusivity of $\mathrm{CO}_{2}$ through chitosan films with proteins incorporated may be explained by the distribution of the protein molecules in the chitosan matrix that causes a decrease of the number of pores, thus decreasing $\mathrm{CO}_{2} \mathrm{P}$. Similar results were obtained when whey protein was added to chitosan films; for lower values of protein content both $\mathrm{O}_{2}$ and $\mathrm{CO}_{2}$ permeability decreased when compared with chitosan films without protein (Di Pierro et al., 2006). 


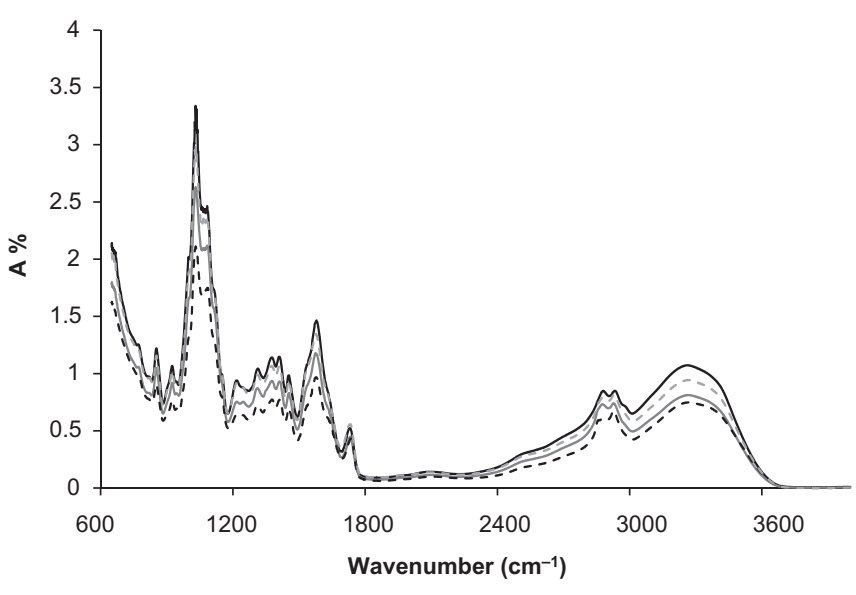

Fig. 3. Spectra of Fourier Transform Infrared (FTIR) for chitosan edible films; (-) chitosan film, (-) chitosan film incorporated with WPC hydrolysate, $(-)$ chitosan film incorporated with GMP, (---) chitosan film incorporated with lactoferrin.

The values obtained for $\mathrm{CO}_{2} \mathrm{P}$ where higher when compared with those of $\mathrm{O}_{2} \mathrm{P}$, which is normally attributed to the solubility of these gases in water. $\mathrm{CO}_{2}$ is more soluble than $\mathrm{O}_{2}$, leading to faster gas diffusion, therefore increasing its permeability (Mujica-Paz and Gontard, 1997). $\mathrm{CO}_{2} / \mathrm{O}_{2}$ permselectivity, defined as the ratio between $\mathrm{CO}_{2}$ and $\mathrm{O}_{2}$ permeabilities, have a great implication in the design of packaging films for food applications (Al-Ati and Hotchkiss, 2003; Park and Chinnan, 1995; Wu et al., 2009). Commercial packaging films have $\mathrm{CO}_{2} / \mathrm{O}_{2}$ permselectivities ranging from 4 to 8 (Al-Ati and Hotchkiss, 2003). A higher ratio indicates less $\mathrm{CO}_{2}$ accumulation and vice versa. The $\mathrm{CO}_{2} / \mathrm{O}_{2}$ permselectivity obtained in this work ranges between 11 and 2 . The highest values were obtained for chitosan films and for chitosan films containing lactoferrin (11 and 7, respectively). For films containing WPC peptide fraction and GMP the values were 2 and 4, respectively.

\subsection{FTIR analyses}

FTIR analyses were used to evaluate possible chemical interactions between the polymeric film and the bioactive agents incorporated in it. Fig. 3 represents the FTIR profile obtained for chitosan films incorporated with different bioactive compounds.

All spectra show similar patterns with absorption peaks at 3330 and $967-1195 \mathrm{~cm}^{-1}$, which corresponds to stretching of $\mathrm{OH}$ and $\mathrm{NH}$ bonds and to stretching of $\mathrm{CO}$ bonds, respectively (Pranoto et al., 2005). Absorption peaks at $2877 \mathrm{~cm}^{-1}$ (C-H stretching) and at $1600 \mathrm{~cm}^{-1}$ (amine groups $\left(-\mathrm{NH}_{2}\right)$ ) were also observed. In addition, the residual lactic acid is evident at $1710 \mathrm{~cm}^{-1}$, corresponding to carbonyl vibration of the carboxylic acid. This peak is a consequence of the low volatility of lactic acid (Lawrie et al., 2007).

The interactions between chitosan and proteins are represented by amide I band (between 1600 and $1700 \mathrm{~cm}^{-1}$ ), amide II (around $1536 \mathrm{~cm}^{-1}$ ) and by $\mathrm{NH}$ and CO deformations (1580-1490 and $1700-1630 \mathrm{~cm}^{-1}$ range, respectively) (Pranoto et al., 2005; Silva et al., 2007). In order to achieve a complete comparison of the interaction between chitosan matrix and the bioactive compounds, a deconvolution of the FTIR spectra (between 1500 and $1700 \mathrm{~cm}^{-1}$ ) for the different films was performed.

The shift of the bands corresponding to the interactions between chitosan and proteins has been previously reported (Cai et al., 2010; Silva et al., 2007). Silva et al. (2007) observed a shift of $\mathrm{NH}$ and $\mathrm{CO}$ deformation bands from 1584 to $1536 \mathrm{~cm}^{-1}$ and from 1650 to $1630 \mathrm{~cm}^{-1}$, respectively, associated with the incorporation of soy protein in chitosan films. On the other hand, Cai et al.
Table 2

List of centroids, fractional areas and assignments of bands between 1500 and $1700 \mathrm{~cm}^{-1}$ for chitosan edible films.

\begin{tabular}{llll}
\hline Assignment & Film & Centroid & \% Area \\
\hline \multirow{2}{*}{ Amide II } & Chitosan film & 1534 & 21.94 \\
& Chitosan film + peptide fraction & 1534 & 21.17 \\
& Chitosan film + GMP & 1533 & 18.22 \\
& Chitosan film + lactoferrin & 1535 & 18.27 \\
NH & Chitosan film & 1583 & 57.74 \\
& Chitosan film + peptide fraction & 1581 & 56.18 \\
& Chitosan film + GMP & 1580 & 56.21 \\
\multirow{2}{*}{ Amide I } & Chitosan film + lactoferrin & 1581 & 60.42 \\
& Chitosan film & 1650 & 20.32 \\
& Chitosan film + peptide fraction & 1648 & 22.64 \\
& Chitosan film + GMP & 1648 & 25.57 \\
& Chitosan film + lactoferrin & 1649 & 21.32 \\
\hline
\end{tabular}

(2010) observed that the incorporation of nisin into a complex with chitosan shifted the place of $\mathrm{OH}$ band (from 3438 to $3417 \mathrm{~cm}^{-1}$ ) and the absorbance bands of asymmetrical and symmetrical COO- vibrations (from 1566 and $1415 \mathrm{~cm}^{-1}$ to 1547 and $1384 \mathrm{~cm}^{-1}$, respectively).

In this work the differences observed were of a much lower magnitude (Table 2) and further studies are needed in order to determine their significance. However, these shifts suggest a specific chemical interaction occurring between functional groups of protein-based bioactive compounds and active groups of the chitosan film.

The interactions between protein-based compounds and the chitosan matrix are also reflected in the area of the bands, which is a measurement of the extent of such interactions. In all cases bioactive compounds addition lead to changes of that area, reflecting different intensities of the chemical bonds established in these materials. These differences may influence the films properties previously described. Specifically, for amide I band the incorporation of bioactive compounds, which affected the hydrophilicity of the samples (Table 1), also resulted in the increase of the\% area. This relationship has been observed in gelatin films (Yakimets et al., 2007).

\section{Conclusions}

Chitosan-based films were used as a matrix for the incorporation of bioactive compounds with different molecular weights. Overall, the incorporation of protein-based compounds in chitosan films resulted in the decrease of the gas permeabilities and TS and in the increase of E. Films' hydrophilicity and crystallinity were successfully related with mechanical and barrier properties. FTIR analyses suggest different intensities of the chemical interaction occurring between functional groups of protein-based bioactive compounds and active groups of chitosan films; these observations are in line with the main results of this work.

The films produced present values of WVP and $E$ in the order of those of cellophane films, TS (for some cases) and $\mathrm{O}_{2} \mathrm{P}$ values in the order of high-density polyethylene (Han and Gennadios, 2005). These results suggest a high potential of these films to be used as active packaging materials, and further studies must be developed in order to access bioactivity and behavior along shelf-life.

\section{Acknowledgements}

The authors gratefully acknowledge LoïcHilliou for the fruitful discussions on the results and Ana Nicolau for helping in confocal analysis. The present work was supported by the project PTDC/ AGR/ALI/67194/2006. The authors M.A. Cerqueira (SFRH/BD/ 23897/2005), M.C. Avides (SFRH/BPD/26913/2006) and M.A.C. 
Quintas (SFRH/BPD/41715/2007) were recipient of fellowships from the Fundaçãopara a Ciência e Tecnologia (FCT, Portugal).

\section{References}

Al-Ati, T., Hotchkiss, J.H., 2003. The role of packaging film permselectivity in modified atmosphere packaging. Journal of Agricultural and Food Chemistry 51 (14), 4133-4138.

Anker, M., Stading, M., Hermansson, A.-M., 1999. Effects of pH and the gel state on the mechanical properties, moisture contents, and glass transition temperatures of whey protein films. Journal of Agricultural and Food Chemistry 47 (5), 1878-1886.

ASTM D882-91, 1991. Standard test methods for tensile properties of thin plastic In: Annual Book of ASTM Standards. Amer. Soc. for Testing \& Materials, Philadelphia, PA.

ASTM D3985-02, 2002. Standard test method for oxygen gas transmission rate through plastic film and sheeting using a coulometric sensor. In: Annual book of ASTM. Amer. Soc. for Testing \& Materials, Philadelphia, PA.

ASTM E96-92, 1990. Standard test methods for water vapor transmission of materials. In: Annual Book of ASTM standards. Amer. Soc. for Testing \& Materials, Philadelphia, PA.

Bravin, B., Peressini, D., Sensidoni, A., 2006. Development and application of polysaccharide-lipid edible coating to extend shelf-life of dry bakery products. Journal of Food Engineering 76 (3), 280-290.

Brown, A.C., Wang, B., Oh, J.H., 2008. Antimicrobial activity of lactoferrin against foodborne pathogenic bacteria incorporated into edible chitosan film. Journal of Food Protection 71 (2).

Cai, J., Yang, J., Wang, C., Hu, Y., Lin, J., Fan, L., 2010. Structural characterization and antimicrobial activity of chitosan (CS-40)/nisin complexes. Journal of Applied Polymer Science 116 (6), 3702-3707.

Caner, C., Vergano, P.J., Wiles, J.L., 1998. Chitosan film mechanical and permeation properties as affected by acid, plasticizer, and storage. Journal of Food Science 63 (6), 1049-1053.

Casariego, A., Souza, B.W.S., Cerqueira, M.A., Cruz, L., Díaz, R., Vicente, A.A., 2009. Chitosan/clay films' properties as affected by biopolymer and clay micro/ nanoparticles' concentrations. Food Hydrocolloids 23, 1895-1902.

Casariego, A., Souza, B.W.S., Vicente, A.A., Teixeira, J.A., Cruz, L., Díaz, R., 2008. Chitosan coating surface properties as affected by plasticizer, surfactant and polymer concentrations in relation to the surface properties of tomato and carrot. Food Hydrocolloids 22 (8), 1452-1459.

Cerqueira, M.A., Lima, A.I.M., Souza, B.W.S., Teixeira, J.A., Moreira, R.A., Vicente, A.A 2009a. Functional polysaccharides as edible coatings for cheese. Journal of Agricultural and Food Chemistry 57 (4), 1456-1462.

Cerqueira, M.A., Lima, Á.M., Teixeira, J.A., Moreira, R.A., Vicente, A.A., 2009b. Suitability of novel galactomannans as edible coatings for tropical fruits. Journal of Food Engineering 94 (3-4), 372-378.

Cuq, B., Gontard, N., Cuq, J.-L., Guilbert, S., 1996. Functional properties of myofibrillar protein-based biopackaging as affected by film thickness. Journal of Food Science 61 (3), 580-584.

Di Pierro, P., Chico, B., Villalonga, R., Mariniello, L., Damiao, A.E., Masi, P., Porta, R. 2006. Chitosan-whey protein edible films produced in the absence or presence of transglutaminase: analysis of their mechanical and barrier properties. Biomacromolecules 7 (3), 744-749.

Durango, A.M., Soares, N.F.F., Andrade, N.J., 2006. Microbiological evaluation of an edible antimicrobial coating on minimally processed carrots. Food Control 17 (5), 336-341.

Fajardo, P., Martins, J.T., Fucinos, C., Pastrana, L., Teixeira, J.A., Vicente, A.A., 2010 Evaluation of a chitosan-based edible film as carrier of natamycin to improve the storability of Saloio cheese. Journal of Food Engineering 101 (4), 349-356.

Farías, M.E., Martinez, M.J., Pilosof, A.M.R., 2010. Casein glycomacropeptide pHdependent self-assembly and cold gelation. International Dairy Journal 20, 7988.

Ferreira, I.M.P.L.V.O., Pinho, O., Mota, M.V., Tavares, P., Pereira, A., Gonçalves, M.P., Torres, D., Rocha, C., Teixeira, J.A., 2007. Preparation of ingredients containing an ACE-inhibitory peptide by tryptic hydrolysis of whey protein concentrates. International Dairy Journal 17, 481-487.

Giménez, B., Gómez-Estaca, J., Alemán, A., Gómez-Guillén, M.C., Montero, M.P. 2009. Improvement of the antioxidant properties of squid skin gelatin films by the addition of hydrolysates from squid gelatin. Food Hydrocolloids 23 (5), 1322-1327.

Gontard, N., Guilbert, S., Cuq, J.-L., 1992. Edible wheat gluten films: influence of the main process variables on film properties using response surface methodology. Journal of Food Science 57 (1), 190-195.

Gontard, N., Guilbert, S., Cuq, J.-L., 1993. Water and glycerol as plasticizers affect mechanical and water vapor barrier properties of an edible wheat gluten film. Journal of Food Science 58 (1), 206-211.

González-Chávez, S.A., Arévalo-Gallegos, S., Rascón-Cruz, Q., 2009. Lactoferrin: structure, function and applications. International Journal of Antimicrobial Agents 33 (4), 301.e301-301.e308.

Han, J.H., Gennadios, A., 2005. Edible films and coatings: a review. In: Han, J.H. (Ed.) Innovations in Food Packagings. Elsevier, Amesterdam, pp. 239-262.

Hartel, R.W., 2001. Crystallization in Foods. Aspen Publishers, Inc., Gaithersburg, MD, pp. 259-265.

Helander, I.M., Nurmiaho-Lassila, E.L., Ahvenainen, R., Rhoades, J., Roller, S., 2001. Chitosan disrupts the barrier properties of the outer membrane of Gram- negative bacteria. International Journal of Food Microbiology 71 (2-3), 235244.

Hiemenz, P.C., Rajagopalan, R., 1997. Surface Tension and Contact Angle, third ed. Marcel Dekker, Inc., New York, pp. 248-255.

Hosokawa, J., Nishiyama, M., Yoshihara, K., Kubo, T., 1990. Biodegradable film derived from chitosan and homogenized cellulose. Industrial and Engineering Chemistry Research 29 (5), 800-805

Keogh, J.B., Woonton, B.W., Taylor, C.M., Janakievski, F., Desilva, K., Clifton, P.M., 2010. Effect of glycomacropeptide fractions on cholecystokinin and food intake. The British Journal of Nutrition 104 (2), 286-290.

Laemmli, U.K., 1970. Cleavage of structural proteins during the assembly of the head of bacteriophage T4. Nature 227 (5259), 680-685.

Lawrie, G., Keen, I., Drew, B., Chandler-Temple, A., Rintoul, L., Fredericks, P., Grøndahl, L., 2007. Interactions between alginate and chitosan biopolymers characterized using FTIR and XPS. Biomacromolecules 8 (8), 2533-2541.

Lin, D., Zhao, Y., 2007. Innovations in the development and application of edible coatings for fresh and minimally processed fruits and vegetables. Comprehensive Reviews in Food Science and Food Safety 6 (3), 60-75.

Lindmark-Månsson, H., Timgren, A., Aldén, G., Paulsson, M., 2005. Two-dimensional gel electrophoresis of proteins and peptides in bovine milk. International Dairy Journal 15 (2), 111-121.

Lu, J.R., Perumal, S., Zhao, X., Miano, F., Enea, V., Heenan, R.R., Penfold, J., 2005 Surface-induced unfolding of human lactoferrin. Langmuir 21 (8), 3354-3361.

Martins, J.T., Cerqueira, M.A., Souza, B.W.S., Carmo Avides, M.D., Vicente, A.N.A., 2010. Shelf life extension of ricotta cheese using coatings of galactomannans from nonconventional sources incorporating nisin against Listeria monocytogenes. Journal of Agricultural and Food Chemistry 58 (3), 1884-1891.

McMillin, K.W., 2008. Where is MAP going? A review and future potential of modified atmosphere packaging for meat. Meat Science 80 (1), 43-65.

Miller, K.S., Krochta, J.M., 1997. Oxygen and aroma barrier properties of edible films: a review. Trends in Food Science and Technology 8 (7), 228-237.

Min, B.J., Han, I.Y., Dawson, P.L., 2010. Antimicrobial gelatin films reduce Listeria monocytogenes on turkey bologna1. Poultry Science 89 (6), 1307-1314.

Mujica-Paz, H., Gontard, N., 1997. Oxygen and carbon dioxide permeability of wheat gluten film: effect of relative humidity and temperature. Journal of Agricultural and Food Chemistry 45 (10), 4101-4105.

Mullally, M.M., Meisel, H., FitzGerald, R.J., 1997. Angiotensin-I-converting enzyme inhibitory activities of gastric and pancreatic proteinase digests of whey proteins. International Dairy Journal 7 (5), 299-303.

Park, H.J., Chinnan, M.S., 1995. Gas and water vapor barrier properties of edible films from protein and cellulosic materials. Journal of Food Engineering 25 (4), 497-507.

Park, S.-I., Zhao, Y., 2004. Incorporation of a high concentration of mineral or vitamin into chitosan-based films. Journal of Agricultural and Food Chemistry 52 (7), 1933-1939.

Pranoto, Y., Rakshit, S.K., Salokhe, V.M., 2005. Enhancing antimicrobial activity of chitosan films by incorporating garlic oil, potassium sorbate and nisin. LWT Food Science and Technology 38 (8), 859-865.

Ribeiro, C., Vicente, A.A., Teixeira, J.A., Miranda, C., 2007. Optimization of edible coating composition to retard strawberry fruit senescence. Postharvest Biology and Technology 44 (1), 63-70.

Rodríguez, M., Osés, J., Ziani, K., Maté, J.I., 2006. Combined effect of plasticizers and surfactants on the physical properties of starch based edible films. Food Research International 39 (8), 840-846.

Sangaj, N.S., Malshe, V.C., 2004. Permeability of polymers in protective organic coatings. Progress in Organic Coatings 50 (1), 28-39.

Sathivel, S., Liu, Q., Huang, J., Prinyawiwatkul, W., 2007. The influence of chitosan glazing on the quality of skinless pink salmon (Oncorhynchus gorbuscha) fillets during frozen storage. Journal of Food Engineering 83 (3), 366-373.

Sebti, I., Coma, V., 2002. Active edible polysaccharide coating and interactions between solution coating compounds. Carbohydrate Polymers 49 (2), 139144

Seol, K.-H., Lim, D.-G., Jang, A., Jo, C., Lee, M., 2009. Antimicrobial effect of [kappa]carrageenan-based edible film containing ovotransferrin in fresh chicken breast stored at $5{ }^{\circ} \mathrm{C}$. Meat Science 83 (3), 479-483.

Shahidi, F., Arachchi, J.K.V., Jeon, Y.-J., 1999. Food applications of chitin and chitosans. Trends in Food Science and Technology 10 (2), 37-51.

Shih, F.F., 1996. Edible films from rice protein concentrate and pullulan. Cereal Chemistry 73 (3), 406-409.

Silva, S.S., Goodfellow, B.J., Benesch, J., Rocha, J., Mano, J.F., Reis, R.L., 2007. Morphology and miscibility of chitosan/soy protein blended membranes. Carbohydrate Polymers 70 (1), 25-31.

Sivarooban, T., Hettiarachchy, N.S., Johnson, M.G., 2008. Physical and antimicrobial properties of grape seed extract, nisin, and EDTA incorporated soy protein edible films. Food Research International 41 (8), 781-785.

Sobral, P.J.A., Menegalli, F.C., Hubinger, M.D., Roques, M.A., 2001. Mechanical, water vapor barrier and thermal properties of gelatin based edible films. Food Hydrocolloids 15 (4-6), 423-432.

Sothornvit, R., Pitak, N., 2007. Oxygen permeability and mechanical properties of banana films. Food Research International 40 (3), 365-370.

Souza, B.W.S., Cerqueira, M.A., Casariego, A., Lima, A.M.P., Teixeira, J.A., Vicente, A.A., 2009. Effect of moderate electric fields in the permeation properties of chitosan coatings. Food Hydrocolloids 23 (8), 2110-2115.

Souza, B.W.S., Cerqueira, M.A., Martins, J.T., Casariego, A., Teixeira, J.A., Vicente, A.A., 2010. Influence of electric fields on the structure of chitosan edible coatings. Food Hydrocolloids 24 (4), 330-335. 
Sperling, L.H., 2006. Introduction to Physical Polymer Science, fourth ed. John Wiley \& Sons Inc., New Jersey.

Srinivasa, P.C., Revathy, B., Ramesh, M.N., Harish Prashanth, K.V., Tharanathan, R.N., 2002. Storage studies of mango packed using biodegradable chitosan films. European Food Research and Technology 215, 504-508.

Srinivasa, P.C., Ramesh, M.N., Tharanathan, R.N., 2007. Effect of plasticizers and fatty acids on mechanical and permeability characteristics of chitosan films. Food Hydrocolloids 21 (7), 1113-1122.

Thomä-Worringer, C., Sørensen, J., López-Fandiño, R., 2006. Health effects and technological features of caseinomacropeptide. International Dairy Journal 16 (11), 1324-1333.

Vargas, M., Albors, A., Chiralt, A., González-Martínez, C, 2009. Characterization of chitosan-oleic acid composite films. Food Hydrocolloids 23 (2), 536-547.
Wu, R.-L., Wang, X.-L., Wang, Y.-Z., Bian, X.-C., Li, F., 2009. Cellulose/soy protein isolate blend films prepared via room-temperature ionic liquid. Industrial and Engineering Chemistry Research 48 (15), 7132-7136.

Yakimets, I., Paes, S.S., Wellner, N., Smith, A.C., Wilson, R.H., Mitchell, J.R., 2007. Effect of water content on the structural reorganization and elastic properties of biopolymer films: a comparative study. Biomacromolecules 8, 1710-1722.

Zhang, B., Wang, D.-F., Li, H.-Y., Xu, Y., Zhang, L., 2009. Preparation and properties of chitosan-soybean trypsin inhibitor blend film with anti-Aspergillus flavus activity. Industrial Crops and Products 29 (2-3), 541-548.

Ziani, K., Oses, J., Coma, V., Maté, J.I., 2008. Effect of the presence of glycerol and Tween 20 on the chemical and physical properties of films based on chitosan with different degree of deacetylation. LWT - Food Science and Technology 41 (10), 2159-2165. 